search for possible contact with animals and, if necessary, removal of the offending animal from the home.

In view of the potentially serious effects of this infection, it is important to consider Cryptosporidium in the differential diagnosis of both acute and chronic diarrhoea in immune compromised subjects.

We thank Dr John Martin for allowing us to report his patient.

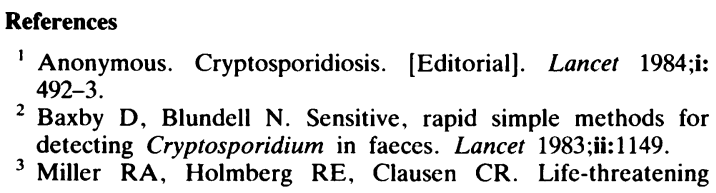

1 Anonymous. Cryptosporidiosis. [Editorial]. Lancet 1984;i: 492-3.

2 Baxby D, Blundell N. Sensitive, rapid simple methods for detecting Cryptosporidium in faeces. Lancet 1983;ii:1149.

${ }^{3}$ Miller RA, Holmberg RE, Clausen CR. Life-threatening

diarrhoea caused by Cryptosporidium in a child undergoing therapy for acute lymphocytic leukaemia. J Pediatr 1983; 103:256-9.

${ }^{4}$ Sloper KS, Dourmashkin RR, Bird RB, Slavin G, Webster ADB. Chronic malabsorption due to cryptosporidiosis in a child with immunoglobulin deficiency. Gut 1982;23:80-2.

5 Anonymous. Cryptosporidiosis: assessment of chemotherapy of males with acquired immunodeficiency syndrome (AIDS). [Editorial]. MMWR 1982;31:589-92.

${ }^{6}$ Koch KL, Shankey V, Weinstein GS, et al. Cryptosporidiosis in a patient with haemophilia, common variable hypogammaglobulinaemia and the acquired immunodeficiency syndrome. Ann Intern Med 1983;99:337-40.

Correspondence to Dr I Lewis, Regional Unit for Paediatric Haematology and Oncology, Alder Hey Children's Hospital, Liverpool L12 2AP.

Received 17 July 1984

\title{
Complications of diazoxide in the treatment of nesidioblastosis
}

\author{
M E McGRAW AND D A PRICE
}

Royal Manchester Children's Hospital

SUMMARY Two children with hypoglycaemia secondary to hyperinsulinaemia were treated with diazoxide. They suffered serious side effects of cardiac failure and truncal ataxia.

The usefulness of diazoxide, a non-diuretic benzothiadizine, in the management of severe hypoglycaemia is well documented. ${ }^{12}$ To date, reported side effects have been minimal and have not affected clinical management. We report two patients in whom severe side effects attributable to diazoxide have been encountered.

\section{Case reports}

Patient 1. This boy was born at 38 weeks' gestation after a normal pregnancy and delivery to a healthy 23 year old mother. His birthweight was $4.5 \mathrm{~kg}$; the birthweights of his two female siblings were $3.7 \mathrm{~kg}$ and $3.5 \mathrm{~kg}$. There was no maternal or family history of diabetes. The parents are both from Pakistan and are first cousins. On examination he was noted to have plethora, a cherubic appearance, length $55 \mathrm{~cm}$ (greater than the 90th centile), and head circumference $34 \mathrm{~cm}$ (50th centile); the remainder of the examination was unremarkable.

At 36 hours he was noticed to be irritable and then had a grand mal convulsion. His blood glucose concentration was $0.8 \mathrm{mmol} / \mathrm{l}(14.4 \mathrm{mg} / 100 \mathrm{ml})$ and he was therefore begun on dextrose infusion of 10 $\mathrm{mg} / \mathrm{kg} /$ minute and intravenous hydrocortisone. $\mathrm{He}$ remained hypoglycaemic until a glucagon infusion was started, after which his glucose concentration became normal. Insulin and $C$ peptide concentrations on two separate occasions confirmed hyperinsulinaemia (insulin 13 and $15 \mathrm{mU} / \mathrm{l}, \mathrm{C}$ peptide 1.6 and $1.8 \mathrm{pmol} / \mathrm{l}(4.8$ and $5.4 \mathrm{ng} / \mathrm{l})$, and glucose 1.0 $\mathrm{mmol} / \mathrm{l}(18 \mathrm{mg} / 100 \mathrm{ml})$ on both occasions. Treatment with oral diazoxide was initiated at $10 \mathrm{mg} / \mathrm{kg} /$ day increasing to a maximum of $22 \mathrm{mg} / \mathrm{kg} / \mathrm{day}$. All other treatment was gradually stopped and by day 15 he maintained a blood glucose concentration around $6 \mathrm{mmol} / \mathrm{l}(108.1 \mathrm{mg} / 100 \mathrm{ml})$ on full oral feeds and diazoxide alone.

On day 18 he became generally unwell with tachypnoea, tachycardia, and poor feeding. On examination he was not feverish, had a respiratory rate of 70 per minute, and a heart rate of 180 per minute with a hyperdynamic right ventricle and a loud systolic murmur heard in the pulmonary area. There was no hepatomegaly and his weight had remained stable. A chest radiograph showed increased lung vascularity and mild cardiomegaly, and an echocardiogram was normal apart from a possible patent ductus arteriosus. Treatment with digoxin and diuretics was begun but there was little cr no clinical improvement. 
On day 33 cardiac catheterisation showed no abnormality and it was felt that his symptoms of cardiac failure were secondary to diazoxide treatment. Diazoxide was gradually reduced and by day 45 his symptoms had resolved on a dose of 2 $\mathrm{mg} / \mathrm{kg} / \mathrm{day}$. Diazoxide was then stopped resulting in a blood glucose concentration of 2.2 to $3.6 \mathrm{mmol} / \mathrm{l}$ $(39.6$ to $64.8 \mathrm{mg} / 100 \mathrm{ml})$ during which time he was completely well.

On day 54 he became clinically and biochemically hypoglycaemic with a blood glucose value of 0.8 $\mathrm{mmol} / \mathrm{l}(14.4 \mathrm{mg} / 100 \mathrm{ml})$. The blood glucose concentration remained under $2 \mathrm{mmol} / \mathrm{l}(36 \mathrm{mg} / 100 \mathrm{ml})$ despite a glucose infusion of $4.5 \mathrm{mg} / \mathrm{kg} /$ minute in addition to oral feeds and so glucagon was given and oral diazoxide recommenced. Despite diazoxide (4 $\mathrm{mg} / \mathrm{kg} / \mathrm{day}$ ) and a diuretic, he required a dextrose infusion of $6 \mathrm{mg} / \mathrm{kg} / \mathrm{minute}$ in addition to oral feeds to maintain a normal glucose concentration. On this treatment he again became tachypnoeic, tachycardic, and fed badly. A subtotal pancreatectomy was performed. Histology confirmed nesidioblastosis.

Patient 2. This boy presented at $81 / 2$ months of age with a two month history of screaming attacks and 'going blank'. He had been born at 36 weeks' gestation with a birthweight of $3.6 \mathrm{~kg}$. He had had no perinatal problems and his subsequent development had been normal. On examination his weight was $10.28 \mathrm{~kg}$ (greater than the 90th centile) and his length and head circumference were on the 50th centile. Investigations showed hypoglycaemia with a blood glucose profile on two hourly feeds of 1.2 to $2.5 \mathrm{mmol} / \mathrm{l}(21.6$ to $45 \mathrm{mg} / 100 \mathrm{ml})$. During this time he was completely asymptomatic. There was no evidence of ketosis; cortisol and growth hormone concentrations and ultrasound of the pancreas were normal. Insulin and $\mathrm{C}$ peptide values when hypoglycaemic were $21 \mathrm{mU} / \mathrm{l}$ and $1.28 \mathrm{pmol} / \mathrm{l}(3.8 \mathrm{ng} / \mathrm{l})$ respectively. His condition became stable on diazoxide $(7.2 \mathrm{mg} / \mathrm{kg} / \mathrm{day})$ with blood glucose levels of 4 to $6 \mathrm{mmol} / \mathrm{l}(72$ to $100 \mathrm{mg} / 100 \mathrm{ml})$. At home he continued to have episodes of hypoglycaemia and the dose was therefore increased to $10 \mathrm{mg} / \mathrm{kg} /$ day.

At the age of 12 months he was readmitted to hospital with a two month history of ataxia. On examination he was found to have noticeable truncal ataxia with no other neurological abnormality. His electroencephalogram and computed tomogram were normal. Subtotal pancreatectomy, considered to be indicated by medical attendants, was refused by the parents. He improved on procyclidine $(1.25$ $\mathrm{mg}$ tds) but the neurological signs did not resolve. As his blood glucose profile showed nocturnal hypoglycaemia (blood glucose 2 to $2.5 \mathrm{mmol} / \mathrm{l}$ (36 to $45 \mathrm{mg} / 100 \mathrm{ml}$ )) diazoxide was increased further to a dose of $10 \mathrm{mg} / \mathrm{kg} /$ day. Over the subsequent year his ataxia has remained a problem, although his development and intelligence quotient remain normal. At the age of 2 years his blood glucose concentration remains stable on $12 \mathrm{mg} / \mathrm{kg} /$ day diazoxide.

\section{Discussion}

In the early series on diazoxide in infancy, ${ }^{2}$ the predominant side effect observed was hypertrichosis lanuginosa. The doses administered were in the range of 10 to $15 \mathrm{mg} / \mathrm{kg} /$ day. More recently ${ }^{3}{ }^{4}$ doses of 20 to $25 \mathrm{mg} / \mathrm{kg} /$ day have been advocated in an attempt to avoid surgery, and more serious side effects on these higher doses may become apparent.

Diazoxide causes a reduction in free water clearance and renal sodium retention, which may lead to cardiac failure ${ }^{5}$ this may be controlled by the concurrent use of a diuretic. Symptoms of cardiac failure in the absence of appreciable weight gain and the failure of response to diuretic treatment led us to suspect a coexisting congenital cardiac anomaly in the first infant. The absence of any such defect poses the question whether diazoxide was exerting a direct cardiotoxic effect, a feature not previously reported. That the child's symptoms were due to treatment is suggested by the clear temporal association between the two.

A wide range of extrapyramidal symptoms ${ }^{6}$ have been observed in $15 \%$ of adults on oral diazoxide during the chronic management of severe hypertension. Their occurrence in children has not previously been described. The gross ataxia seen in our second patient was felt to be extrapyramidal in origin and was improved, although not abolished, by antiParkinsonian treatment. In view of the risk of hypoglycaemia and parental reluctance to subtotal pancreatectomy, we were unable to stop diazoxide, and thus polypharmacy was felt to be a justifiable alternative to surgery.

Diazoxide proved a useful and effective agent in controlling hypoglycaemia in both of our patients. Treatment was complicated, however, by serious side effects which necessitated stopping it in one patient. With the more widespread use of diazoxide in higher doses, clinicians should be aware of the wide range and potentially serious nature of the side effects that may be encountered.

\footnotetext{
References

${ }^{1}$ Drash AL, Wolff FW. Drug therapy in leucine sensitive hypoglycaemia. Metabolism 1964;13:87-91.

2 Baker L, Kaye R. Diazoxide treatment of idiopathic hypoglycaemia in infancy. $J$ Pediatr 1967;71:494-505.

${ }^{3}$ Sovik $\mathrm{O}$, Vidnes J, Falkner S, et al. Persistent neonatal hypoglycaemia. Acta Pathol Microbiol Scand IA] 1975;83: 155-66.
} 
4 Aynsley Green A, Polak JM, Bloom SR, et al. Nesidioblastosis of the pancreas: definition of the syndrome and the management of the severe neonatal hyperinsulinaemic hypoglycaemia. Arch Dis Child 1981;56:496-508.

5 Dukes MNG, ed. Meylers side effects of drugs. Vol VIII. Amsterdam: Excerpta Medica, Elsevier, 1976:473.

6 Neary D, Thurston H, Pohl JEF. Development of extrapyra- midal symptoms - hypertensive patients treated with diazoxide. Br Med J 1973;iii:474-5.

Correspondence to Dr D A Price, Royal Manchester Children's Hospital, Manchester M27 1HA.

Received 6 October 1984

\section{Accidents in Malawi}

\section{SIMMONS}

Charing Cross Hospital Medical School, London

SUMMARY The frequency and types of children's accidents during a two month period in Malawi are described, showing that these are at least as numerous as in developed countries. It is suggested that preventive measures and an improvement in immediate treatment are required.

Accidents are the most common cause of child death in developed countries. ${ }^{1}$ In developing countries their importance is often overshadowed by the problems of infection and malnutrition; however, where valid statistics are available, accidents are at least as numerous. ${ }^{1}$ This study describes the frequency and types of children's accidents in Malawi, Central Africa during a two month period.

\section{Methods}

The survey was carried out in Kamuzu Central Hospital, Lilongwe, which serves a district of 850000 and includes an urban population in the nation's capital and a rural population. It is also a referral centre for the 2.6 million people of the Central Region of Malawi.

All admissions to the paediatric ward during July and August 1983 were recorded. Details of accidental injuries including age, sex, site of accident, objects involved, type and site of wound, and whether or not the child died were obtained from hospital records and where possible, parents were interviewed to corroborate this information.

In addition to the hospital study, a house to house survey was carried out in conjunction with a blood pressure survey in a housing estate in the city and in a rural village 22 miles from the city. Details on all children who had experienced an accident in the two months before the interview and whether this had resulted in a visit to the local health centre were recorded.

\section{Results}

Seventy seven $(9 \cdot 7 \%)$ of the 777 paediatric hospital admissions in the two month period were the result of accidents (Table 1). Overall, more boys than girls were admitted to hospital because of an accident, but there was no significant difference in the proportion of admissions between boys and girls. The proportion of admissions due to accidents increased with age.

Burns and scalds accounted for $21(27 \cdot 3 \%)$ of the accidents and were the commonest cause of hospital admission in children aged under 4 years; two children subsequently died. All the burns resulted from falling into open fires in the home. Two thirds of the burns affected more than one area of the body. One of the burns followed an epileptic fit, a more frequent occurrence than is suggested by this study. The events described are an 'aura' of feeling cold, moving to the fireside for warmth, and subsequently fitting and falling into the fire.

Fractures $(25(32 \%))$ were the commonest single

Table 1 Accidents as a proportion of hospital admissions

\begin{tabular}{lccccc}
\hline Age & \multicolumn{2}{l}{ Total no of admissions } & & \multicolumn{2}{l}{$\begin{array}{l}\text { Total no of accidents } \\
\text { (\% of admissions) }\end{array}$} \\
\cline { 2 - 3 } \cline { 5 - 6 } & Boys & Girls & & Boys & Girls \\
\hline 1 & 118 & 118 & & $3(2 \cdot 5)$ & $4(3 \cdot 4)$ \\
$1-4$ & 223 & 169 & & $22(9 \cdot 9)$ & $15(8 \cdot 9)$ \\
$5-9$ & 64 & 48 & & $16(25 \cdot 0)$ & $11(22 \cdot 1)$ \\
$10-14$ & 16 & 19 & & $3(18 \cdot 9)$ & $1(5 \cdot 3)$ \\
Not known & 1 & 1 & 1 & 1 \\
Total & 422 & 355 & $45(10 \cdot 7)$ & $32(9 \cdot 0)$ \\
\hline
\end{tabular}

$\chi^{2} / \mathrm{df}$ boys $v$ girls, $\mathrm{P}>0.05$. 